\title{
Project Based Learning: In Pursuit of Androgogic Effectiveness
}

\author{
Berrington X. S. Ntombela ${ }^{1}$ \\ ${ }^{1}$ Faculty of Arts, Department of English, University of Zululand, KwaDlangezwa, Republic of South Africa \\ Correspondence: Berrington X. S. Ntombela Faculty of Arts, Department of English, University of Zululand, \\ Private Bag X1001, KwaDlangezwa 3886, Republic of South Africa. Tel: 27-35-902-6791. E-mail: \\ ntombelab@unizulu.ac.za
}

Received: December 12, 2014 Accepted: January 27, 2015 Online Published: March 25, 2015

doi:10.5539/elt.v8n4p31 URL: http://dx.doi.org/10.5539/elt.v8n4p31

\begin{abstract}
In an attempt to standardise Foundation Programmes for Oman higher education providers, the Oman Academic Standards for General Foundation Programmes stipulated that higher education providers should offer programmes that ensure androgogic effectiveness. In the light of that, this paper presents attempts by a University College in Oman to introduce project based learning through a 'Project' component offered at Foundation level. However, in establishing the androgogical learning theory it became necessary to consider the seemingly inflated false dichotomy between pedagogy and androgogy by way of highlighting learning theories that underpin project based learning. Furthermore, the paper shows how skills that are thought to be transferable from 'Project' to other components fall short due to 'Project' being a subject on its own rather than an approach which compromises the envisaged androgogic effectiveness. Nonetheless, benefits of 'Project' as a subject component are presented in the form of soft skills which are mainly the expected learning outcomes. Therefore, the paper proposes the implementation of project based learning in ensuring pedagogical relevance and androgogic effectiveness among higher education providers and further demonstrates the extent at which this is realised in the university college where the study was conducted followed by recommendations based on the findings of this study.
\end{abstract}

Keywords: androgogy, pedagogy, project based learning, $21^{\text {st }}$ century skills, six-step approach

\section{Introduction}

One of the unique general characteristics of students in the Gulf, particularly in Oman, is that the majority entering post-secondary education, first have to go through a foundation programme designed to bring their general academic abilities to the level required for tertiary education. It is upon this reality that Oman Academic Standards for General Foundation Programme (OAC for GFP) was drafted, aimed inter alia at ensuring that standards maintain their androgogic effectiveness (OAC for GFP, 2007, p. 5). This study looks into how androgogy as a learning theory gets realized through 'project based learning', which is introduced as a 'Project component' at Foundation level in a university college in Oman.

\section{Androgogy}

Although the term androgogy dates as far back as 1833, coined by a German teacher, Kapp (Hiemstra \& Sicso, 1990); it was popularized and developed into a learning theory by Malcolm Knowles (Belfast Institute, n.d.; Hiemstra \& Sisco, 1990; UBC Health Library Wiki, 2010). The term androgogy which is also spelled andragogy literally comes from 'the Greek word 'aner', with the stem 'andra' meaning 'man'... or 'adult', and 'agogos' meaning 'leader of'” (Holmes \& Abington-Cooper, 2000, p. 51). Knowles (1980, p. 43) however defined the term as "the art and science of helping adults learn."

It should be noted that Knowles's popularization of androgogy came mostly as a reaction to pedagogy which he regarded as not fitting to adult education. In fact, he had observed that most adult learning took place informally in clubs and social groups, not classrooms (Belfast Institute, n.d.). Therefore, the role of the tutor was viewed as being leader and facilitator, not teacher as it is the case with pedagogic theories (ibid).

Knowles further differentiated androgogy from pedagogy by asserting five assumptions that explain how and why adults learn (UBC Health Library Wiki, 2010; Belfast Institute, n.d.):

1) Self-concept assumes that an adult is no longer dependent upon someone, but is matured enough to discern and decide upon learning goals and needs. 
2) Experience assumes that adults have a wide spectrum of exposure which they use as a learning resource.

3) Readiness explains the ability of adults to face learning due to roles they have already assumed in the society.

4) Orientation means that matured adults expect learning to be readily applicable to problems they wish to solve.

5) Motivation for adults is largely intrinsic.

There has however been a long debate on whether Knowles's claims on andragogy represent learning or teaching theory; or whether they simple mean good practice. This was fueled, inter alia by the fact that the assumptions about adult learners also apply to child learners in varying degrees. Hence, Knowles later revised his claims stating that he then saw andragogy as "another model of assumptions about learners to be used alongside the pedagogical model of assumptions, thereby providing two alternative models for testing out the assumption as to their "fit' with particular situations" (Knowles, 1980, p. 43 in Holmes \& Abington-Cooper, 2000, p. 52). Nevertheless, andragogy managed to influence adult education although some scholars criticized it for being teacher-centred.

Hase and Kenyon (2000), for example, argue that pedagogical and androgogical methods still heavily rest on the relationship between the teacher and the learner, where the former traditionally decides what the later needs to know and how that knowledge and skills should be taught. They (ibid) therefore propose heutagogy, which they define as "the study of self-determined learning" where there is recognition for the need to be flexible in the learning and where the teacher provides resources whilst the learner designs the actual course he or she might take by negotiating the learning. They (ibid) in fact envision courses offered using the internet and intranet as providing superb opportunities for the use of a heutagogical approach where delivery gives the hope of increased learner-learner and learner-teacher interaction through chat rooms and email lists. Moreover, they (ibid) strongly contend that this would enable the control of learning to shift more appropriately to the learner.

Notwithstanding, many courses in adult education are designed following Knowles' andragogical principles. For example Oommen (2009, p. 171) reports the success of a course offered to Omani adult employees, emphasizing andragogical concepts underpinning the course design. Furthermore, contrary to Hase and Kenyon's (op cit.) line of argument, Merriam (2001, p. 6) maintains that "andragogy remains the most learner-centred of all patterns of adult educational programming." This takes us to project based learning, which is largely received as a typically learner-centred approach.

\section{Project Based Learning}

Project based learning is viewed by Cook $(2006$, p. 3) as a departure from approaches that typically view teachers' roles as transmitting information to children to be remembered and thus are preoccupied with instructing through sequencing content, drilling, correcting, and testing. These approaches are based on behaviorist theories that, according to Buck Institute for Education (BIE) (2010, p. 3), support traditional direct instruction as opposed to Piaget's social-constructivist theory, which suggests shift of the teacher's preoccupation from that of 'instruction' to the child's 'construction' (De Vries \& Kohlberg, 1990, p. 374).

It is clear, therefore, that project based learning is grounded on constructivism that regards learners as actively constructing "frameworks of understanding... by using both the knowledge they already possess, and new information presented to them" (Mahar \& Harford, 2005, p. 8). Constructivism is further regarded as a move from teacher-centred approaches based on behaviorist principles, to a much more learner-centred view, where learners are actively involved in creating their own individual learning environment (Belfast Institute, n.d.).

Thus, BIE (2010) defines project based learning (PBL) as a "systematic method that engages students in learning knowledge and skills through an extended inquiry process structured around complex, authentic questions and carefully designed products and tasks." However, "under the larger umbrella of PBL are two types of project based learning" viz. "place-based learning and problem-based learning" (Small schools project.org, 2003). Whilst place-based learning "incorporates elements of service learning and environmental education with project-based structure", problem-based learning education "emphasizes skill building through real-world challenges" (ibid). On the other hand, Felder and Brent (2004) classify "problem-based learning, inquiry-based learning, discovery learning, need-to-know learning, and just-in-time learning" under the inductive approaches. Along with these is project-based learning, which, according to Felder and Brent (2004), "means that most of the learning in a course takes place in the context of projects, with lectures playing a subsidiary role or not taking place at all."

Since PBL is learner-centred it marks a shift from a traditional teacher's role of being the instructor par excellence to that of a facilitator, a resource person and a guide. Most of the learning activity is carried out by learners who could initiate projects and could drive them to whatever direction that suits their learning needs 
(Trepainier-Street, 1993).Therefore, in order to best explain the teaching learning theory that underpins PBL we shall refer to the analogy of 'hands on-hands off' principle that is best represented by a continuum with opposite poles; one representing a teacher and the other a learner. On either end there is dominance of either 'hands on' or 'hands off'. If 'hands on' dominates the teacher's pole it signifies a deductive approach, which is traditionally teacher-centred, whereas if 'hands on' dominates the learner's pole it shows the inductive approach, which is learner-centred. The following diagram demonstrates this principle.

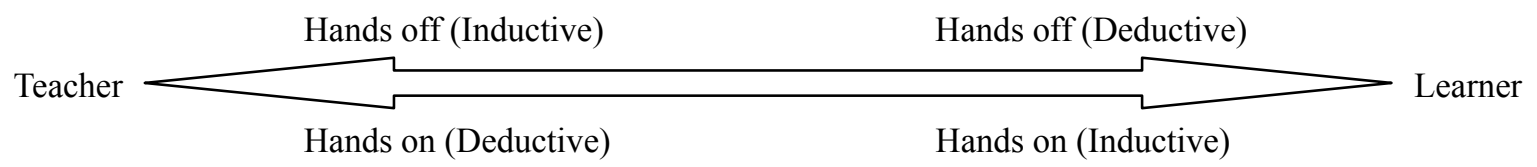

Figure 1. 'Hands on', 'Hands off' Principle

Therefore, BIE (2001) contends that "the student role in PBL becomes one of carrying out self-directed learning activities rather than carrying out teacher directed activities; defining their own roles, tasks and time management rather than receiving and completing brief, directed tasks; learning how to communicate, show, affect, produce, take responsibility rather than listen, behave, speak only when spoken to." Most notably, PBL "refocuses the use of technology from an ancillary or peripheral use to a central and integral part of the process; from technology administered by teachers to technology directed by students; from technology useful for teacher presentations to technology enhancing student presentations" (BIE, 2001).

In line with the objectives of this study we shall consider the 'Project Component' (hereafter Project) that follows the principles of PBL as offered as part of the Foundation Programme in the University College in Oman.

\section{Project}

Ntombela (2010, p. 600) reports that Project was designed as a reaction from Industrial Interaction Group (IIG) which criticized new graduates who were found wanting in soft skills. As a result, Project was crafted with an aim of achieving learning outcomes such as team work, meeting deadlines, critical thinking, and research skills (Foundation 1 Module Descriptor, 2009, p. 3). In fact, as Blake (2009) reports, students are engaged in three projects throughout the duration of the course. These projects are (i) Staff portrait gallery in which students collate information about college staff members that they have interviewed; (ii) Pamphlet which is meant to communicate survey results that students have undertaken around a college theme, for instance Road Safety; and (iii) Class magazine that presents information collected through an interview and a survey about college issues that should be presented in an informative and entertaining manner. Most importantly, Project relies heavily on the six-step approach that underpins the mode of delivery and learning (Ntombela, 2010, p. 600), which necessitates that we look at this approach closely.

\section{The Six-Step Approach}

This approach which is also known as Blank Page Method (BPM) (Blake, 2009; Walker, 2009a) literally consists of six sequential steps (think, research, plan, write, edit, present) that students must apply when undertaking their projects; needless to say that behind each step is a rationale discussed below.

\subsection{Think}

Thinking, which rests on the notion that it is the first logical step to take when approaching any task, occurs when students initially brainstorm through a spider diagram. Walker (2009a, pp. 4-6) notably emphasizes that brainstorming using a spider diagram is the most effective and practical way as it helps students record their ideas in whatever order they deem necessary, without having to worry about, say order of importance that potentially hampers the flow of ideas. Furthermore, she (ibid, pp. 18-19) asserts that ideas represented by the 'legs' of the spider make it conducive for students to add as many ideas without having to worry about space, which is often the case with a list format. Like most of the steps, as we shall see, thinking works best when done in teams as opposed to individually (Ntombela, 2010, p. 600).

\subsection{Research}

During this step students find information through interviews, surveys, internet, library, etc. Ntombela (2010, p. 601) contends that since thinking stage opens a myriad of ideas for students, researching helps narrow the scope so that their focus is more on the topic or subject of investigation. It is expected that each team, after assigning 
roles to all members, appoints a leader whose duty is to ascertain that the remit is addressed accordingly. For instance, in the first project where students gather information through interviews, the leader secures an appointment with the interviewee and assigns two members to carry out the interview, whilst the rest of the members contribute questions.

\subsection{Plan}

Although the amount of information gathered during the researching stage has a better shape than during the thinking stage, it still needs categorization that must ensure that only the required information is recorded appropriately. This takes place during planning stage where students also decide how the information will be presented as required in the remit. For example, students might decide that, say in the magazine project, their names as contributors would be in the front or back page.

\subsection{Write}

Students should now find it easier to execute their plan. During writing stage, the team spirit is still enforced in a way that each student must contribute a potion, say introduction, conclusion, or a paragraph in the body, etc. This measure is meant to discourage strong students from depriving weak ones of giving their best.

\subsection{Edit}

It is imperative that students constantly refer to the remit as they progress with the project. This is even more so during the editing stage as students consider whether their writing has responded to the remit, or whether they have not left any crucial information. They also address errors and correct mistakes; first on their own, then by the teacher.

\subsection{Present}

Students' project culminates with the showcasing of their effort that occurs during presenting stage. At this stage they attend to the final product making sure it meets the expectations of the recipient. Walker $(2009 \mathrm{~b}, \mathrm{p} .10,12)$ emphasizes that the importance of students paying close attention to the presentation of their project lies on the understanding that "if beauty is in the eye of the beholder we better make sure that we capture the attention of that eye."

More than being a course delivery mechanism, BPM is student-driven: it is the strategy students employ when attacking any academic task (Caledonian College of Engineering (CCE), 2010, p. 12). This strategy is enforced through projects, which also ensures student-centredness. Therefore, it calls for a shift on the traditional role of the teacher from being the centre of the learning process to that of students taking responsibility for their own learning. This is in line with what PBL entails, as discussed above. This also seems to imply more learner independence which Knowles (op cit.) associated with adult learners. Most interestingly, recently there has been a move towards developing students for $21^{\text {st }}$ century learning, (the discussion of which follows) which seems to profile learners in the same manner as PBL and Knowles'androgogic principles.

\section{6. $21^{\text {st }}$ Century Learning}

In order to prepare students to succeed in the $21^{\text {st }}$ century a vision has been drafted with specific outcomes for a twenty first century student. According to Partnership for $21^{\text {st }}$ Century Skills (2009), students need to learn a range of skills such as critical thinking, problem solving, communication and collaboration in order to succeed in the modern global economy. These skills are said to differentiate students who are prepared for success in the current work environment from those who are not (ibid).

According to Bellanca and Brandt (2010, p. 5), $21^{\text {st }}$ century skills could best be achieved through problem-based learning where teachers are meant to "shift their standards-based curriculum from direct instruction of passive students to active engagement of problem solvers and question askers." In other words, there are greater expectations that students would be directly involved in learning, with teachers playing a subsidiary role and that is why PBL is seen as an ideal tool to foster $21^{\text {st }}$ century skills. In fact, Pearlman in Bellanca and Brandt (ibid, p. 118) strongly contends that due to changes resulting from inter alia new technology tools that enable more learner-centred approaches to education, schools need to move away from teacher-directed whole group instruction to create learner-centred workplaces for collaborative culture of students at work. He (ibid, p. 119) believes that the teacher should now be regarded as less of an instructor or typical lecturer to a guide that allows students to teach themselves.

Most proponents of $21^{\text {st }}$ century skills are driven by the surge of technology in the society in general and particularly in schools where education does not seem to reflect that reality. Many (Tapscott, 1998; Prensky, 2001; Kelly, McCain, \& Jukes, 2009) subscribe to the notion that the present generation of students belongs to 
'digital natives,' which necessitates configuration of pedagogy in such a way that it addresses their capabilities which have been enhanced much more than the previous generation (Pearlman in Bellanca \& Brandt, 2010, p. 118). It seems the ideal way of making sure that such students are catered for is through PBL, where student-learning centres around a project with all these technological tools available for them to complete their work, just as it happens in the real work environment.

\section{Discussion}

From Knowles' assumptions that define adult learners on which andragogic principles are founded, we gather that learning and teaching are expected to shift from the teacher and place the learner at the centre. This is done to reflect the fact that adult learners determine what, how and when they want to learn. This places the onus more on them than on the teacher who simple acts as a guide on the choices they have made, and the facilitator of the learning they have engaged themselves. Nevertheless, we have also mentioned that just as many commentators and scholars argued, these assumptions do not just generally represent adult learners per se, but are reflective of good practice as they seem to feature in many schools' programmes such as those that follow PBL.

At the heart of PBL is the realization that learning should be student-driven. Students are encouraged to be active and to take initiative in their learning. They are given projects that instill self-dependency, collaboration, and critical thinking among other skills that they acquire. This rewrites the teacher's role from that of a traditional instructor and controller to a facilitator who creates opportunities for students to discover as they learn; guides them towards realization of their learning and measures the extent at which they have acquired knowledge. Most importantly, PBL rests on inductive methodologies which, as demonstrated, allow learners 'hands on' experience in their learning. This is evident in the Project Component offered in the university college where this study is based, which is also aimed at ensuring that the course carries andragogic effectiveness.

As discussed above, students in Project go through six steps to complete their projects. These steps are meant to give them a structure they could use in approaching any piece of academic work, but goes beyond just that; students acquire a range of skills such as critical thinking, listening, oral or verbal, time-management, and most notably teamwork. During Project work students are largely left on their own, only consulting the teacher when they get stuck or not sure whether they are addressing the remit; i.e. they are expected to be able to go through all the stages of their Project on their own. These expectations are in sync with andragogic assumptions and notably with the framework for $21^{\text {st }}$ century learning.

$21^{\text {st }}$ century learning promotes pedagogic and curriculum changes ensuring that they are reflective of the current trends in the digital age and modern economies. Notably, $21^{\text {st }}$ Century adopted PBL because, among other reasons, it exposes students to a multifaceted approach, which characterizes modern age. It is worth considering that most of these changes are reported in the schooling system, yet are reflective of Knowles' adult education.

Therefore, we can deduce that andragogic principles cannot be confined to adult learners nor be received as adult traits per se, but are what education ought to strive for at all levels. That is, these assumptions carry the same weight for school going students whose education should reflect the dynamics of modern world as it does with adult ones. In that respect, PBL appears to equip learners across the spectrum with the necessary skills and experience demanded in the present generation.

Nonetheless, we should guard against being quickly sold to the notion that $21^{\text {st }}$ century outcomes and vision apply mutatis mutandis to all sectors of education regardless of geographic, cultural, historical, economic, and developmental dispersal; for reality points to the fact that whilst other countries are far ahead in development others lag behind in extreme conditions. If therefore, technological advancement in the society generally dictates the route that education should take in order to remain relevant to the student population's aspirations and modernity, those in disadvantaged countries should not be overburdened by what would appear irrelevant to their immediate environment even when such carries tremendous weight among their developed counterparts. This calls for innovative approaches to PBL that matches the needs of each student population environment.

Thus, as mentioned before, Project was principally designed because the students' immediate need was the lack of soft skills that are desired in the work place. The BPM that is adopted and thought to be transferrable to other components is the underlying feature in Project, and is in fact regarded as a learner strategy and not a teaching methodology (CCE, 2010, p. 12). That is, students are given a strategy that tries to demonstrate how problems should be approached in real work situations. For example, there is a notable emphasis on the thinking stage because of the observation that students tend to rely more on the teacher for problems that need own thinking. Similarly, there is equal emphasis on the importance of doing things in teams as it reflects the reality of the present work ethos; gone are those days where for instance, an engineer would enclose him or herself in the office aloof and detached from other employees. 
However, although students get repeated exposure and practice of the six-step approach, seemingly there is no success in transferring the skills to other components.It is reported by Ntombela $(2010$, p. 605) that teachers who offered Project felt that it was not possible to directly transfer BPM to other components without explicitly making reference to it. The main explanation to that is that Project is not necessarily an approach in the same way as PBL, but a subject aimed at imparting soft skills among the students. If it was an approach, the other components would also feature projects, which is not the case. As a result, the strategies that Project brings are most likely to be interpreted by students as applicable to the Project component and not automatically transferable to others. In fact, Katz (1994) argues that project work is not to be viewed as a separate subject like say Mathematics; rather, it provides a context for applying mathematical skills and concepts. Moreover, Project does not offer students an opportunity to initiate and drive projects to the direction that suits their needs, as suggested by Trepainer-Street (1993); on the contrary, the teacher determines the project, lays specific remit and judges the outcome of the project based on the observations carried throughout the project. Therefore, although students carry out projects on their own, the fact that everything from the nature of the project to the outcome is determined by the teacher, it makes the process teacher-centred, and thus compromises androgogic principles of independence and self-reliance. As an approach, Project should therefore be able to offer students skills that should be useful in other projects that should be ideally offered in other components.

When it comes to Oman's higher educational realities, it should be highlighted that the Ministry of Higher Education-which is fairly recent, having been established in 1994-is responsible for supervising post-secondary education in universities, institutes and colleges (World Data on Education, 2011). This responsibility principally entails 'setting up, designing and executing the educational policies in the Sultanate of Oman' (ibid, p. 3). There seems to be a drive towards aligning the educational system to reflect the realities of the $21^{\text {st }}$ century. For example, recent curricular reforms, in the schooling sector have focused on, inter alia, '(i) introducing new subjects such as information technology, environmental life skills and computer studies; (ii) ensuring the transfer of skills and knowledge into the students' practical world; and (iii) adopting student-centred learning approaches' (ibid, p. 9).

As it has been discussed, these reforms have no conflict with androgogic principles where for instance, students take initiative of their learning without having to rely heavily on the teacher as it is the case with teacher-centred approaches. Furthermore, the transference of skills is possible with the adoption of PBL as students grapple with issues and challenges that are relevant in their immediate environment. All of this seems possible with the influx of information technology and proliferation of computer literacy in the modern student populace.

\section{Conclusion}

The present educational context seems to dictate that teaching and learning process should be learner driven. We have discussed that androgogic principles are not just true for adult learners, but apply equally for most learners in general. We have also argued that the approach that seems to translate such a move is an inductive approach in which PBL grounds its principles. This is further demonstrated by the rise of $21^{\text {st }}$ century skills that seek to equip students with modern day work oriented approach to learning. Project component has been presented as a model that the university college where the study is based offers, with not only the aim of helping learners acquire soft skills, but of hoping to transfer the same skills to other components. We have however argued that since Project, in this case, is not an approach but a subject, chances of transferring skills to other components are jeopardized; and also because projects are largely teacher initiated, androgogic principles appear compromised.

\section{References}

Belfast Institute. (n.d.). Learning theories. Department of Learning and Teaching Resources. Retrieved July 27, 2010, from http://www.belfast.ac.uk/goal/Resources/learningtheories-cg-withvideo3/index.htm

Bellanca, J., \& Brandt, R. (2010). $21^{\text {st }}$ Century Skills: Rethinking how students learn. Solution Tree Press: Bloomington.

Blake, R. C. (2009). The New Foundation Programme. Presented at the School of Foundation Studies meeting. Muscat: Caledonian College of Engineering.

Buck Institute for Education. (2001). Project-based learning. Retrieved February 28, 2010, from http://www.smallschoolsproject.org/PDFS/Planning-Resources/Spring2003-pbl.pdf

Buck Institute for Education. (2010). What is PBL? Retrieved June 1, 2010, from http://www.bie.org/about/whatispbl

Caledonian College of Engineering. (2010). Overview of the Caledonian College of Engineering Foundation Programme. Muscat: Caledonian College of Engineering. 
Cook, P. R. (2006). The Project Approach: An appreciation for the constructivist theory. University of Windsor: Forum on Public Policy.

DeVries, R., \& Kohlberg, L. (1990). Constructivist early education: Overview and comparison with other programmes. Washington, DC: National Association for the Education of Young Children.

Felder, R. M., \& Brent, R. (2004). The ABC's of engineering education: ABET, Blooms taxonomy, Cooperative learning, and so on. Proceedings of the 2004 American Society for Engineering Education Annual Conference \& Exposition. Retrieved July 28, 2010, from http://www4.ncsu.edu/unity/lockers/users/f/felder/ public/papers/ASEE04(ABCs).pdf

Foundation 1 module descriptor. (2009). School of Foundation Studies. Muscat: Caledonian College of Engineering.

Hase, S., \& Kenyon, C. (2000). From andragogy to heutagogy. Ultibase Articles. Retrieved July 29, 2010, from http://ultibase.rmit.edu.au/articles/dec00/hase2.htm

Hiemstra, R., \& Sisco, B. (1990). Individualizing instruction-Moving from pedagogy to andragogy. San Francisco: Jorsey-Bass. Retrieved June 27, 2010, from http://www.distance.syr.edu/andragogy.html

Holmes, G., \& Abington-Cooper, M. (2000). Pedagogy vs. andragogy: A false dichotomy? The Journal of Technology Studies, 26(2), Summer/Fall. Retrieved June 26, 2010, from http://scholar.lib.ut.edu/ejournals/ JOTS/Summer-Fall-2000/pdf/holmes.pdf

Katz, L. G. (1994). The project approach. Retrieved October 29, 2010, from http://www.ericdigests.org/ 1994/project.htm

Kelly, F. S., McCain, T., \& Jukes, I. (2009). Teaching the digital generation: No more cookie-cutter high schools. Thousand Oaks, CA: Corwin Press.

Knowles, M. S. (1980). The modern practice of adult education. New York: Cambridge. The Adult Education Company.

Mahar, S., \& Harford, M. (2005). Research on human learning. Melbourne: Department of Education and Training.

Merriam, S. B. (2001). Andragogy and self-directed learning: Pillars of Adult learning theory. Retrieved June 26, 2010, from http://www.fsu.edu/ elps/ae/download/ade5385/Merriam.pdf

Ntombela, B. X. S. (2010). Acquisition of soft skills. Proceedings of the Asian Conference on Arts and Humanities (pp. 597-608). Osaka: IAFOR.

Oman Academic Standards for General Foundation Programs. (2007). Retrieved August 28, 2009, from http://www.oac.gov.om/files/assurance/draft_standards/gfp_standards_v4.pdf

Oommen, A. (2009). Adult education and independent learning: Equipping employees. Proceedings of the Ninth Annual ELT Conference-Responding to challenges in curriculum, assessment and independent learning ( $22^{\text {nd }}$ to $23^{\text {rd }}$ April 2009). Muscat: Sultan Qaboos University.

Partnership for $21^{\text {st }}$ Century Skills. (2009). Framework for $21^{\text {st }}$ Century Learning. Retrieved July 27, 2010, from http://www.pri.org/documents/p21-Framework.pdf

Pearlman, B. (2010). Designing new learning environments to support $21^{\text {st }}$ century skills. In J. Bellanca, \& R. Brandt (Eds.), $21^{\text {st }}$ Century skills: Rethinking how students learn. Bloomington: Solution Tree Press.

Prensky, M. (2001, October). Digital natives, digital immigrants. On the Horizon, 9(5), 1-6. Retrieved July 27, 2010, from http://www.marcprensky.com/writing/Prensky-digitalNatives,digitalImmigrants-Part1.pdf

Small schools project.org. (2003). Project-based learning. Retrieved February 28, 2010, from http://www.smallschoolsproject.org/PDFS/Planning-Resources/Spring2003-pbl.pdf

Trepainer-Street, M. (1993). What's so new about the Project Approach? Childhood Education, 70. Retrieved February 28, 2010, from http://www.questia.com/googlescholar.qst;sessionid=LhwFtHBTGh7TydGcpx105 GgvI

UBC Health Library Wiki. (2010). Adult learning theory (androgogy). Retrieved June 6, 2010, from http://hlwiki.slais.ubc.ca/index.php/Adult_learning_theory_(androgogy)

Walker, J. (2009a). Language and Learning 1: Project Unit 3. Muscat: Caledonian College of Engineering

Walker, J. (2009b). Language and Learning 1: Project Unit 4. Muscat: Caledonian College of Engineering 
World Data on Education, Oman. (2011). $7^{\text {th }}$ Edition. UNESCO-IBE. Retrieved January 2, 2015, from http://www.ibe.unesco.org/

\section{Copyrights}

Copyright for this article is retained by the author(s), with first publication rights granted to the journal.

This is an open-access article distributed under the terms and conditions of the Creative Commons Attribution license (http://creativecommons.org/licenses/by/3.0/). 